\title{
Competitiveness of Industrial Companies Forming the Value Chain of Wind Energy Components: The Case of Lithuania
}

\author{
Akvile Cibinskiene $^{1, * \mathbb{C}}$, Daiva Dumciuviene ${ }^{1} \mathbb{C}$, Viktorija Bobinaite ${ }^{2}$ and Egidijus Dragašius ${ }^{3} \mathbb{C}$ \\ 1 School of Economics and Business, Kaunas University of Technology, Gedimino str. 50, \\ LT-44239 Kaunas, Lithuania; daiva.dumciuviene@ktu.lt \\ 2 Lithuanian Energy Institute, Laboratory for Energy System Research, Breslaujos str. 3, \\ LT-44403 Kaunas, Lithuania; viktorija.bobinaite@lei.lt \\ 3 Faculty of Mechanical Engineering and Design, Kaunas University of Technology, Studentu str. 56, \\ LT-51424 Kaunas, Lithuania; egidijus.dragasius@ktu.lt \\ * Correspondence: akvile.cibinskiene@ktu.lt; Tel.: +370-687-77771
}

\section{check for}

updates

Citation: Cibinskiene, A.; Dumciuviene, D.; Bobinaite, V.; Dragašius, E. Competitiveness of Industrial Companies Forming the Value Chain of Wind Energy Components: The Case of Lithuania. Sustainability 2021, 13, 9255. https:// doi.org/10.3390/su13169255

Academic Editors: Baojie He, Ayyoob Sharifi, Chi Feng and Jun Yang

Received: 21 July 2021

Accepted: 13 August 2021

Published: 18 August 2021

Publisher's Note: MDPI stays neutral with regard to jurisdictional claims in published maps and institutional affiliations.

Copyright: (c) 2021 by the authors. Licensee MDPI, Basel, Switzerland. This article is an open access article distributed under the terms and conditions of the Creative Commons Attribution (CC BY) license (https:/ / creativecommons.org/licenses/by/ $4.0 /)$.

\begin{abstract}
Sustainable energy development has attracted attention worldwide, partly because of the value chain of the wind energy industry that focuses on the overall value creation and innovation. In order to achieve not only ambitious goals in the fight against climate change, but also to create significant economic benefits for European Union citizens, it is necessary to ensure the production of renewable energy components in Europe itself and in Lithuania at the same time. This paper aims to evaluate the competitiveness of Lithuanian companies that manufacture wind energy components. The research was conducted applying methods such as a survey of manufacturers of wind energy components, expert assessment and descriptive analysis. The results of the competitiveness assessment revealed that the existing conditions and trends are favourable for the development of their performance and strengthening of their competitiveness. The government solutions to promote industry could facilitate the performance of companies operating in the value chain of wind energy components and encourage new companies to join it. This would encourage the Lithuanian industry to expand its participation in the value chain of the European Union's renewable energy industry, create more jobs, and increase the added value.
\end{abstract}

Keywords: wind power industry; manufacturers of wind energy components; value chain of wind energy components; competitiveness

\section{Introduction}

Sustainable energy development has attracted attention around the world, partly because of the value chain of the wind energy industry that focuses on overall value creation and innovation. The global wind energy industry is going through major changes. The development of renewable and sustainable energy technologies makes the wind energy industry more intense, efficient, greener and more complex in terms of value creation. It is therefore intended to minimize value-added operations and maximize value creation as much as possible. The value chain model of the wind energy industry allows for a comprehensive analysis of the factors forming the value chain of wind energy components (VCWEC), to determine the overall value creation process.

In order to achieve not only ambitious goals in the fight against climate change, but also to create significant economic benefits for European Union (EU) citizens, it is necessary to ensure the production of renewable energy components in Europe itself and in Lithuania at the same time. Lithuania proposes to include wind production and energy storage technologies in the EU's strategic value chain. The EU needs a stable and strong industrial sector and research and development (R\&D) efforts to become a leader in the developing renewable energy technologies. 
It is strategically important to invest rapidly and actively in the recovery and growth of the Lithuanian economy after the COVID-19 crisis. Firstly, it is vital to exploit the situation and ensure a sustainable, innovative and high-value-added economy. It is also vital to attract investment, reduce dependence on the Asian market and shorten and diversify the value chains. Finally, it is important to increase their resilience, create new jobs and ensure the extraction of green energy and the supply of this energy to other sectors.

Wind energy is one of the types of "green" energy which can address the aforementioned issues. In detail, due to the development of offshore and onshore wind energy, people are supplied with jobs, which accounted for 300,000 jobs in EU in 2019, and the economy is supplied with growth, which was generated from value-added contributions of EUR 37.2 billion and exports in goods and services of EUR 8 billion [1]. Furthermore, wind energy made relevant contributions to the local economy through taxes, which were of EUR 1.3 billion (not linked to corporate profit) and were designated to local governments and communities [1], and income for farmers in a form of lease payments to landlords of the area [2]. Indeed, in the presence of rising carbon and fuel prices, energy demand and more [3], the low operating cost of wind energy [2] kept wholesale electricity prices low and decreasing $[3,4]$. Being a local industry, wind energy reduced the country's dependence on polluting fossil fuels [5], helped stabilize the cost of electricity and reduced vulnerability to price spikes and supply disruptions [2]. Beyond the economic benefits, wind energy is relevant for environmental purposes as it reduces greenhouse gas (GHG) emissions [6], including lifecycle GHG emissions [7]. The latest research demonstrates that the known environmental, economic and other benefits of wind energy might even be larger in monetary terms if novel solutions are adapted, including wind farm layout optimization $[5,8]$.

Changes, trends, forecasts, and investments of strategic importance to the country require detailed analysis and substantiation. In order for Lithuania to successfully solve the tasks mentioned above and join the VCWEC manufacturing, research of Lithuania's opportunities and perspectives in this field is essential and relevant, not only in the country's context, but also in the context of the EU.

The World Economic Forum (WEF) defines competitiveness as the ability of a country or firm to create more wealth than its competitors under global market equilibrium [9]. The Organization for Economic Co-operation and Development (OECD) argues that competitiveness under favourable market conditions shows the extent to which a firm can produce goods and services for an internationally competitive market while synchronizing real domestic income and growth in living standards [10]. The International Institute for Management Development (IMD) defines competitiveness as an effective mean of achieving growth in living standards and social well-being [11].

Although the concept of competitiveness has been used and applied in research for a relatively long time, there are many studies of the competitiveness of various types of companies, industries and countries. In addition, the regular calculation and publication of national competitiveness indices are promoted (Global Competitiveness Index (WEF), World Competitiveness Rating (IMD), the European Regional Competitiveness Index (European Commission)). In general, competitiveness shows the ability of a company to make business decisions using its available resources, which allows it to occupy a higher position than its competitors do. Therefore, the competitiveness assessment can provide valuable insights in evaluating the development opportunities, perspectives and resilience of the companies forming the VCWEC.

This paper aims to evaluate the competitiveness of Lithuanian companies that manufacture wind energy components (WEC).

The results of this research can provide insights for the Lithuanian government to take actions that will encourage the Lithuanian industry to participate more widely in the value chain of the EU's renewable energy industry, including wind energy, create more jobs and increase added value. 


\section{Theoretical Background of Competitiveness Assessment}

The origins of competitiveness are linked to the ability of individual countries to accumulate more wealth. This concept was later developed and adapted to various levels, not just countries. It was taken into account that the country's assets depend on the industries and individual companies operating within it. In this way, the factors that may affect competitiveness are starting to be examined, and models for competitiveness assessment are created.

\subsection{The Concept of Competitiveness and the Levels of Its Assessment}

The representatives of the mercantilist worldview may be considered the pioneers of the country's competitiveness and the analysis of its factors. In the 14th century, they held the position that a country that is able to accumulate more wealth by promoting exports and restricting imports is in a better position. A. Smith's [12] concept of absolute advantage and D. Ricardo's [13] theory of comparative advantage, which states that a country has a comparative advantage in the production of a certain product when the opportunity cost of this product is lower than in other countries, can also be considered as the basics of a competitiveness assessment. The representatives of classical and neoclassical economic theory paid great importance to trade, which ensures the country's competitiveness. According to them, competitiveness is gained by being able to profit from international trade by exporting expensive products or services produced cheaply and using inexpensive raw materials. Competitiveness was later developed within the framework of Shumpeter's theory of entrepreneurship and innovation, the Porter Diamond model and even later in Krugman's [14] theory of new economic geography criticizing competitiveness [15].

The term "competition" is derived from the Latin word concurrentia, which means collision and embarrassment [16]. The concept of "competitiveness" is treated slightly differently by many authors. Porter [17] can be considered as the originator of the modern concept of competitiveness, and he argued that competitive advantage could be understood as "a country's ability to create an environment that enables companies to develop and innovate faster than foreign competitors". According to Fang et al. [18], the definition of competitiveness varies depending on the context, scale and purpose of its application.

A review of the concepts of competitiveness presented by various authors shows that this category can be examined in very different ways. Summarizing the research of many authors, Travkina and Tvaronavičienè [19] state that a country's competitiveness can be analysed by levels (micro, meso, macro), areas (economics, politics, society and technology) and time perspectives (medium or long term). Only the same levels of competitiveness can be compared. However, we can observe that the competitiveness of the lower level (e.g., companies) forms the competitiveness of the higher level (industry), and this also affects the overall competitiveness of the country [20]. This dependence of the country's economic competitiveness on the competitiveness of its constituent industries, which in turn depend on the competitiveness of enterprise that is determined by the competitiveness of employees, was also revealed by Reiljan, Hinrik and Ivanov [21].

\subsection{The Assessment of Competitiveness}

Many different models can be found to assess competitiveness. Balkyte and Tvaronavičiene [22] state that many economists develop competitiveness models to adapt them to different factors that affect competitiveness. The broader the analysis of competitive advantages, the more complex the model is, leading to differences in the views of researchers, even when assessing at the same sectors or industries.

One of the most commonly used models for competitiveness assessment is the Porter Diamond Model [17]. It covers four main groups of factors that affect national competitiveness: factor conditions, demand conditions, related and supporting industries and firm strategy, structure and rivalry.

Factor conditions. This group of factors includes the factors of production needed to compete in a given industry. These factors include human resources (quantity of labour, 
skills, costs, etc.), physical resources (natural resources or raw materials used in production, their quantity, quality, price, availability; they may also include the country's natural or climatic conditions), knowledge resources (scientific, technical knowledge resources), capital (amount of capital, cost) and infrastructure (types of infrastructure, quality and cost of use).

Demand conditions. These are the conditions that shape the demand for manufactured products or services in domestic and foreign markets. In the absence of demand, it is hardly possible to achieve competitiveness.

Related and supportive industries. Nowadays, this is often referred to as a cluster of a particular industry or activity. These are industries or companies that are geographically close to each other, interact, collaborate or complement each other with their specific activities. These may include local suppliers or scientific and other organizations.

Firm strategy, structure and rivalry. It is the internal organization, management and strategy of a company that can affect its competitiveness in one way or another.

In addition to these four main groups of factors, Porter [17] adds government and a chance that can affect all four main groups of factors. Direct intervention, significant technological discoveries, jumps in factor prices, significant changes in financial markets, jumps in exchange rates, fluctuations in global and regional demand, political decisions of foreign governments, wars and pandemics are considered as a chance. Porter treats the government not as a factor of the Diamond model but rather as an influencer of its structure and efficiency.

Although the Porter Diamond model has been supplemented and refined in various ways, the main groups of factors identified have become the basis for the various models used in the research. It has become popular for competitiveness assessment because it covers the key elements that shape competitiveness, and the factors that affect each key element can be chosen flexibly depending on the object of the research.

\section{Porter Diamond Competitiveness Assessment Model for Assessing the Competitiveness of Enterprises Forming the VCWEC}

Zhao et al. [23] used the Diamond model to assess the performance and competitiveness of the Chinese wind energy industry, and Liu et al. [24] applied it to a review of the value chain of the Chinese wind energy industry. Irfan et al. [25], with the help of this model, examined the main factors affecting the Indian wind energy industry. Fang et al. [18] applied this model to assess the competitiveness of national renewable energy in the G20. They took only the four main factor groups of the Porter Diamond model for the assessment of national renewable energy competitiveness but combined it with the indicator system. Zhao et al. [23] applied the improved dynamic Diamond model, which includes government as the fifth determinant that directly affects all main groups of factors except for factor conditions. However, one of the factors under the group of factor conditions discussed in that study includes programs and projects that might be initiated by the government. Therefore, the determinant government should affect the factor conditions as well. Technology in that model is incorporated as an intermediate variable, affecting only demand conditions and firm strategy, structure and rivalry. Under the technology Zhao et al. [23] discuss technical R\&D; R\&D capacity building and standards and norms building. These elements may have an impact not only on demand conditions and firm strategy, structure and rivalry but also on factor conditions and related and support industries. The chance in this model has influence only on factor conditions and firm strategy, structure and rivalry but in fact may have influence on the other main Diamond model factor groups. Irfan et al. [25] applied the Diamond model with the core four groups of factors with government and chance both affecting all main elements. Technology in this case was not included as an element of the model but showed up in the analysis under the chance and firm strategy, structure and rivalry. Although Zhang et al. [26] discuss Porter's Diamond model for the international competitiveness of China's wind turbine manufacturing industry, they did not apply it for evaluation. 
Summarizing the performed research of wind energy competitiveness, the adapted Diamond model to assess the competitiveness of Lithuanian companies forming the VCWEC was applied (Figure 1).

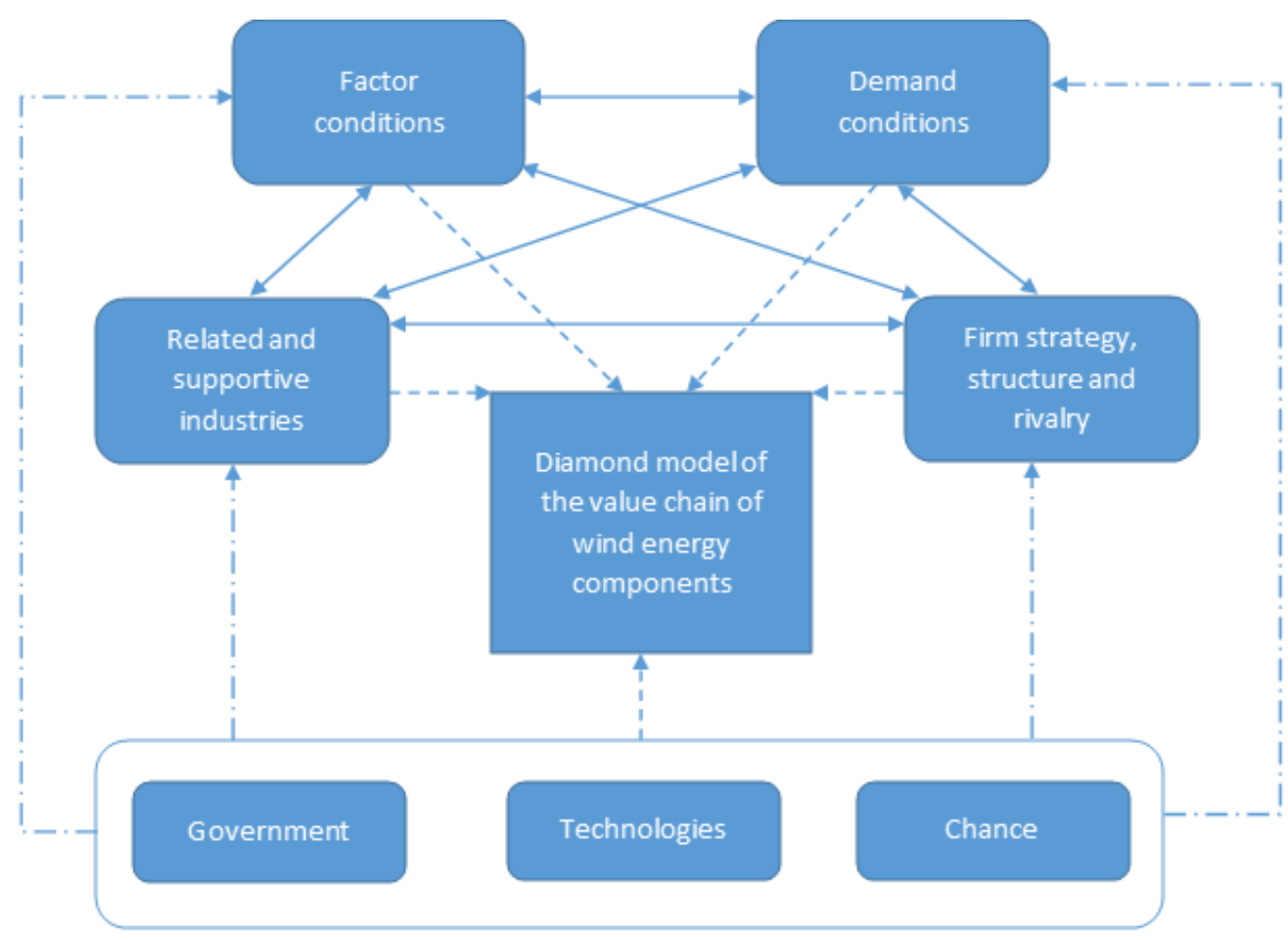

Figure 1. Diamond model of the VCWEC (adapted according to Liu et al. [24]).

In assessing the competitiveness of the wind energy industry according to the Diamond model, foreign authors have assigned to Porter's selected factor conditions the appropriately selected factors relevant to each activity. The authors studying the competitiveness of the wind energy industry, renewable energy and wind energy industry value chain have assigned the following factors to the respective groups of factors in the Porter's Diamond model:

- Factor conditions: availability of resources; capital injections; level of technology; skilled labour; wind resource potential; changes in energy structure; programs and projects; production costs and electricity price in the grid.

- Demand conditions: market size; substitution costs; environmental requirements; policy incentives; energy demand; installed wind capacity; energy supply conditions; wind energy rejection and off-grid wind power.

- Firm strategy, structure and rivalry: local renewable energy companies; specialization; technological innovations; differentiation strategies; vertical integration and social capital investments.

- Government: laws and regulations; political decisions; taxes and government support.

- Technologies: energy storage; construction of ultra-high voltage electricity transmission networks; technical R\&D; increase of R\&D capacity; development of standards and norms.

- Chance: wind industry opportunities (rich wind resources; high energy demand; government support; decrease of wind energy production costs; increasing share of wind energy in the country's total energy balance; local economic development), wind industry challenges (unbalanced distribution of wind energy resources; inefficient and obsolete wind farms, lack of financial mechanism and economic incentives, resistance to wind energy projects, need for capital, dependence on foreign technologies). 
As can be seen, some of the above-mentioned factors of the assessment of the competitiveness of Lithuanian VCWEC companies cannot be applied since they were applied at another level of research and become irrelevant in this case. Examples of these factors include local renewable energy companies as a factor in the firm strategy, structure and rivalry of companies. In the case of this study, the element must include the companies that form the VCWEC.

Fang et al. [18] singled out the substitution costs under the demand conditions when examining the competitiveness of renewable energy, which was considered as a possible change in energy prices due to the changed energy structure (an increasing share of energy from renewable sources may lead to an increase in the price to the final consumer, leading to fewer consumers choosing to buy energy from renewable sources). This study chooses the domestic and foreign market demand for "green" products as factors with similar meaning. Fang et al. [18] also included in the demand conditions a factor of political incentives that may encourage consumers to abandon fossil fuel energy and choose energy from renewable energy sources, which may affect demand. The Diamond model used in this study distinguishes a separate group of "government" factors that affect all the major groups of the other factors. Therefore, the factors related to government decisions were assigned to the group of "government" factors in this study. The wind energy rejection factor singled out by Liu et al. [24] is associated with possible restrictions on the supply of wind energy due to the limited capacity of China's transmission networks. The off-grid energy factor examined by Zhao et al. [23] is also specifically relevant to the Chinese market, as it relates to wind energy that is generated in rural areas and consumed locally, which cannot be supplied to the broader market as it would be economically inefficient to build power transmission lines to these areas. Due to the specifics of these factors, which are relevant to the Chinese market and not relevant in Lithuania, they were not included in this study. The manufacturers of WEC are classified as a group of related and supporting industries by Fang et al. [18], Irfan et al. [25] and Zhao [23], as they examined the competitiveness of wind (renewable) energy. In the case of this study, the factor is attributed to the firm strategy, structure, and rivalry because the manufacturers of WEC are competitors to the firms in question. Typically, the output of manufacturers of WEC is very specific and only in rare cases can one manufacturer of WEC be a supplier or customer to the other component manufacturers. For this reason, they are not included in the group of related and supporting industries in this study. Irfan et al. [25] assigned a specialization factor to firm strategy, structure, and rivalry, emphasizing on firm specialization to achieve competitive advantage. In this study, Lithuanian manufacturers of WEC usually produce a wider range of products, only one part of which is WECs; therefore, the inclusion of this factor in the study becomes meaningless. The opportunities and challenges of a chance for foreign authors are related to the conditions of demand and factors, as well as government and technology elements, and therefore, these factors are not applied in this study. To describe a chance in this study, price spike, shortage of raw materials, supply disruptions and other factors are used.

Irfan et al. [25] attributed the technological innovation factor to the element of firm strategy, structure and rivalry, but in the case of this study, it is more appropriate to attribute it to the element of technology. The factors "energy storage" and "construction of ultra-high voltage electricity transmission networks" that were attributed to the group of technological factors by Liu et al. [24] are not relevant for manufacturers of WEC in this study, therefore, they were further omitted.

Summarizing the factors applied in the research of foreign authors, as well as the factors of the business environment, statistics and analysis of the current situation, the following factors in assessing the competitiveness of Lithuanian VCWEC were singled out.

\section{Factor conditions:}

- $\quad$ skilled labour costs;

- cost of energy used in the production process;

- $\quad$ price of other production inputs; 
- $\quad$ origin of raw materials;

- cost of capital borrowing;

- changes in the investment environment;

- potential of wind energy resources;

- changes in energy structure;

- $\quad$ EU and national business support;

- diversity of business financing sources and access to them;

- changes in the exchange rate;

- inflation;

- $\quad$ status of production facilities;

- lack of requested qualification staff.

\section{Demand conditions:}

- foreign market demand for "green" products;

- domestic market demand for "green" products;

- energy demand;

- demand structure;

- demand dynamics;

- $\quad$ installed wind energy capacity.

\section{Related and supporting industries:}

- $\quad$ wind turbine manufacturers;

- grid constructors;

- raw material suppliers;

- sales intermediaries.

\section{Firm strategy, structure and rivalry:}

- differentiation strategies;

- export;

- competitors.

\section{Government:}

- $\quad$ targets and support measures for increasing the production and consumption of energy from renewable sources in Lithuania;

- EU and Lithuanian emission reduction targets;

- energy efficiency targets and support measures;

- regional development policy, its objectives and support measures;

- requirements for the management and utilization of waste generated in the production process;

- phase out of subsidies for fossil fuels;

- taxes.

\section{Technologies:}

- implementation of the latest technologies;

- dynamics of technological change and innovation implementation;

- expenditure on R\&D.

Chance: price spike, shortage of raw materials, supply disruptions.

\section{Methods of Assessing the Competitiveness of Enterprises Forming a VCWEC}

Various quantitative and qualitative methods are used to assess competitiveness according to the Porter's Diamond model. The applied method is determined by the selected competitiveness assessment factors and data describing them. It is difficult to limit oneself to quantitative methods, as not all of the selected factors can be quantified or there is a lack of quantitative data. Some of identified competitiveness factors for this study describe the business environment, another part is the analysis of statistical data and the third part is the answers to purposefully formulated questions for companies in the questionnaire. Irfan et al. [25], Liu et al. [24] and Zhao et al. [23] performed a competitive assessment 
using the method of descriptive analysis. Zhang [26] and Fang et al. [18] used quantitative methods to assess competitiveness. However, in their case, the number of competitiveness factors was lower, and they performed an international competitiveness assessment comparing the competitiveness of renewable energy producers and international wind power producers in different countries, respectively.

In order to cover as many factors of competitiveness of the companies forming the VCWEC as possible, a descriptive logical analysis, a questionnaire survey and an expert assessment were used. The results of the survey of manufacturers of WEC allow for the simultaneous assessment of the business environment and the factors shaping the competitiveness. Based on these, it is possible to draw conclusions about the influence of individual groups of competitiveness factors on the competitiveness of the companies in question. The expert assessment was applied to assess the business environment and the significance of various individual groups of competitiveness factors. In our case, the experts selected were the representatives of energy and industry associations.

The general aim of the survey of manufacturers of WEC was to identify and describe the peculiarities of these companies' performance in terms of the group of products they produce and could produce in future, the share of WEC in the total production value, the historical development of sales volumes of WEC, the export markets and the shares of exports, the customers they deal with, the trade intermediaries they have, the competitors in domestic and foreign markets, the purchases of raw materials, the post-sale services they provide, the participation in $R \& D$, the factors of business environment they face, the issues they meet and the role of government improving the conditions for performance. The survey was constructed based on the questionnaire, which consisted of 24 questions covering the activities mentioned above. This paper focuses mainly on responses of the manufacturers of WEC to questions about the factors of the business environment. The identified factors were grouped considering the PEST analysis method which allowed for an analysis of the Political, Economic, Sociodemographic and Technological determinants of the business environment. The manufacturers of WEC were asked to assess whether the factors provide opportunities or threats to their participation in the VCWEC and, later on, to assess the strength of this impact on a scale from 1 of 5 , where:

- 1 -very small opportunity or threat;

- 2-small opportunity or threat;

- 3-medium opportunity or threat;

- 4-high opportunity or threat;

- 5-very high opportunity or threat.

In addition, if manufacturers of WEC supposed that the factor of business environment is irrelevant to their participation in the VCWEC, they could scale it as of impact 0 , which means it is insignificant factor.

From the practical perspective, the scaled strength of the impact on opportunities should be understood as the opportunity to increase production value, earn net profit, grow, increase exports, enter new markets or achieve other benefits, which are adjusted to the core aim of that company. In contrast, the scaled strength of the impact on threats means that the factor of the business environment contradicts the main aim of that company's performance and results. A rating of 0 means that the factor of business environment is insignificant as it does not impact the performance and results of manufacturer. No numerical values were attributed to measures of opportunities and threats; therefore, manufacturers were left with personalized understanding. Such a decision was made by the Authors of this paper with the purpose to normalize the responses.

The expert assessment aims to assess how strongly the factors of the political, economic, sociodemographic and technological environment impact the participation of companies in VCWEC and evaluate the importance of the factors determining the competitiveness of these companies. The expert assessment questionnaire consisted of seven questions. Of these, four questions were designed to assess the factors of the business environment according to the opportunities and threats (on a scale from 1 to 5 , see above), one question 
on the assessment of the importance of groups of competitiveness factors (on a scale from 1 of 5) and two open-ended questions. One open-ended question was asked to find out the reasons that prevent companies from getting involved in the VCWEC, as this may not have been reflected in the assessment of business environment. The second open question sought to find even more companies involved in the manufacture of WEC that could be interviewed.

The assessment of the competitiveness of the companies forming the Lithuanian VCWEC was carried out in three stages, as shown in Figure 2.

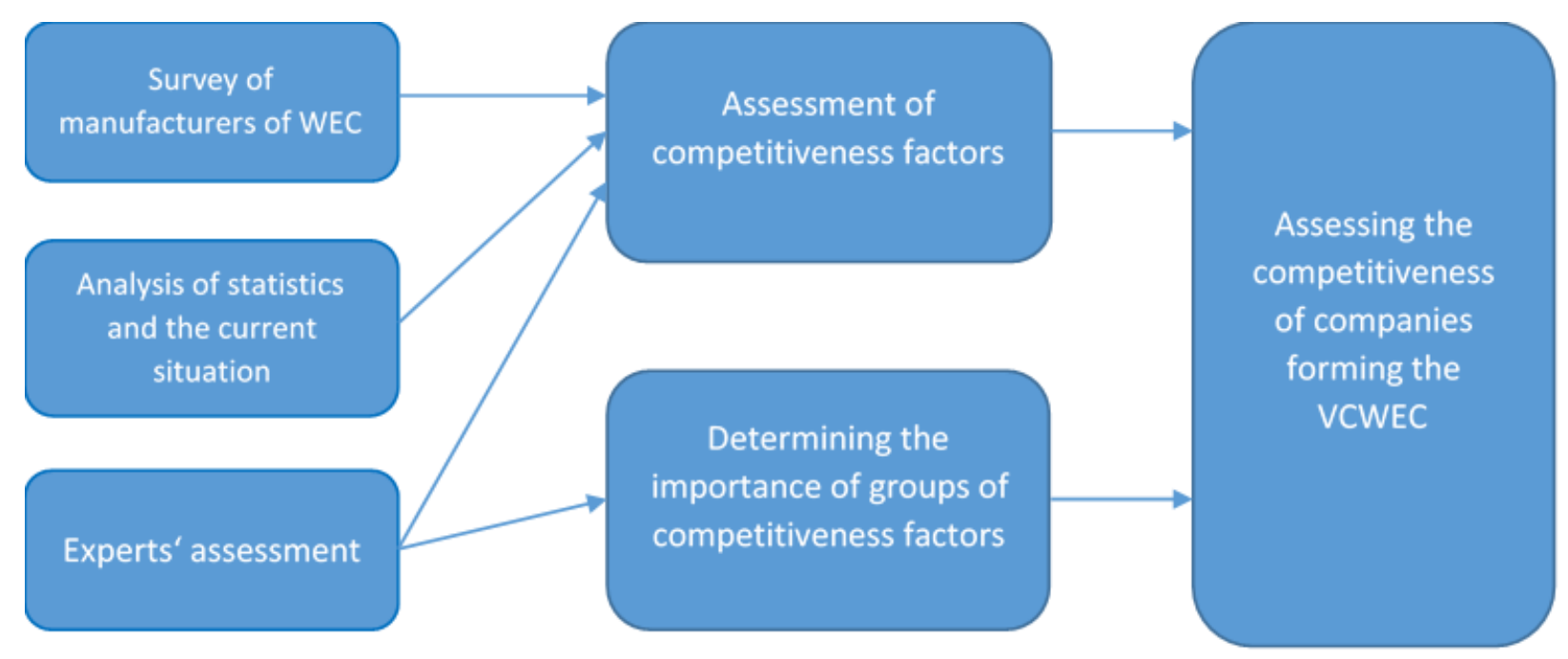

Stage 1

Stage 2

Stage 3

Figure 2. The assessment of the competitiveness of the companies forming the Lithuanian VCWEC.

Factors that describe both the business environment and the results of the analysis of statistics and the current situation were selected to assess the competitiveness of the companies forming the VCWEC. Thus, in the first stage of the research, a survey of companies, experts' assessment, analysis of statistics and the current situation were carried out. In the second stage of the study an analysis of the data collected during the first stage is performed, i.e., assessing competitiveness factors and determining the importance of groups of competitiveness factors. By combining the evaluations carried out in the second stage, their results are summarized in the third stage.

During the research, 25 manufacturers of WEC were identified and contacted electronically by sending the questionnaires or the references to questionnaires during 1 March 2021 and 5 July 2021. In total, seven manufacturers of WEC sent their responses. The responses about business environment factors were summarized considering the weighted average method, which was applied for assessments of factors providing both opportunities and threats. Four experts participated in the survey. Since there have not been many manufacturers forming Lithuanian VCWEC, many industrial associations could not be experts. An expert assessment was organized electronically between 28 May 2021 and 14 June 2021 by sending the questionnaires or the references to experts.

The Kendall concordance coefficient was used to assess the level of coincide (similarity) of experts' opinions [27], as follows:

$$
W=\frac{12 S}{m^{2}\left(n^{3}-n\right)}
$$


where $m$-number of experts, $n$-number of assessed (rated) factors and $S$ - sum of squares of deviations from the mean:

$$
\begin{gathered}
S=\sum_{i=1}^{n}\left(R_{i}-\bar{R}\right)^{2} \\
R_{i}=\sum_{j=1}^{m} r_{i j}
\end{gathered}
$$

where $\bar{R}-R_{i}$-the average and $r_{i j}$-assessment of $i$-th factor of $j$-th expert.

The Kendall concordance coefficient can take values from 0 to 1 . The closer the value of the coefficient to 1 is, the more similar the opinions of the experts are.

\section{Results of Research on Competitiveness of Manufacturers Forming VCWEC 5.1. Assessment of Competitiveness Factors of VCWEC}

The calculated overall Kendall concordance coefficient of all experts' responses indicates a mean concordance of opinions, as it is 0.556 . The greatest agreement is reached on the impact of the factors of the sociodemographic and economic environments on the participation of Lithuanian manufacturers in the VCWEC. The greatest difference of opinion, on the other hand, is in the assessment of the importance of the factors determining the competitiveness of manufacturers participating in the VCWEC and the impact of the factors of technological environment (Table 1).

Table 1. Values of the Kendall concordance coefficient by groups of factors: case of research of Lithuanian VCWEC.

\begin{tabular}{|c|c|c|}
\hline Group of Factors & $\begin{array}{c}\text { Assessment of Positive Impact } \\
\text { (Opportunities) }\end{array}$ & $\begin{array}{c}\text { Assessment of Negative Impact } \\
\text { (Threats) }\end{array}$ \\
\hline Factors of political environment & 0.430 & 0.490 \\
\hline Factors of economic environment & 0.651 & 0.580 \\
\hline Factors of sociodemographic environment & & 0.816 \\
\hline Factors of technological environment & 0.308 & 0.272 \\
\hline Factors impacting on competitiveness & & 0.556 \\
\hline $\begin{array}{c}\text { Total (based on all groups of factors) value of } \\
\text { Kendall concordance coefficient }\end{array}$ & & \\
\hline
\end{tabular}

According to experts, within the group of factors of the political environment, the EU and Lithuanian emission reduction targets, regional development policies, aims and supporting policies provide large opportunities to manufacturers of WEC. The first factor creates assumptions to increase demand for WEC, but the second factor creates assumptions to develop WEC business in regions having wind energy potential and relevant infrastructure, such as seaports. The medium threats come from the requirements for the management and utilization of waste generated in the production process. In the group of factors of the economic environment, increasing foreign and domestic market demand for "green" products, active EU and national support for business, as well as access to variety of business financing sources bring the WEC business medium to large opportunities; while increasing prices of goods and services, growth of production cost, as well changes of exchange rate are recognized as unfavourable conditions. The threats they cause are assessed as medium to very high. The experts singled out the shortage of requested qualification staff and emigration as a source of threat within the group of factors of the sociodemographic environment but agreed that immigration, education and society's improving attitude towards "green" products provide opportunities. The status of production facilities, implementation of new technologies and innovation, development of general infrastructure and expenditure on R\&D are assessed as providing opportunities to manufacturers of WEC under the technological environment.

Based on the factors singled out in the literature review, eight factors of the economic environment, one factor of technological and sociodemographic environment, two factors 
describing the external environment and one factor to the question about raw materials used in the production of WEC were prescribed to a group of factor conditions. The impact of environmental factors was estimated as an average of manufacturers of WEC and expert assessment. The descriptive analysis to assess other factors was used (Table 2).

Table 2. Assessment of competitiveness factors: a group of factor conditions.

\begin{tabular}{|c|c|c|}
\hline Factor Conditions & Description & Assessment \\
\hline Status of production facilities & Factor of technological environment & Opportunities 4.0 \\
\hline EU and national business support & Factor of economic environment & Opportunities 3.4 \\
\hline Changes in the investment environment & Factor of political environment & Opportunities 3.1 \\
\hline $\begin{array}{l}\text { Diversity of business financing sources } \\
\text { and access to them }\end{array}$ & Factor of economic environment & Opportunities 2.9 \\
\hline Lack of requested qualification staff & Factor of sociodemographic environment & Threats 4.0 \\
\hline Skilled labour cost & Factor of economic environment & Threats 2.9 \\
\hline Cost of capital borrowing & Factor of economic environment & Threats 2.9 \\
\hline Price of other production inputs & Factor of economic environment & Threats 2.8 \\
\hline Changes in exchange rate & Factor of economic environment & Threats 2.2 \\
\hline Inflation & Factor of economic environment & Threats 2.0 \\
\hline $\begin{array}{l}\text { Cost of energy used in production } \\
\text { process }\end{array}$ & Factor of economic environment & Threats 1.9 \\
\hline Origin of raw materials & $\begin{array}{l}\text { Question in the questionnaire: } 1 \text { Where } \\
\text { does the company procure materials and } \\
\text { raw materials for the production of wind } \\
\text { energy components? }\end{array}$ & $\begin{array}{l}56 \% \text { of manufacturing companies } \\
\text { purchase raw materials in EU markets, } \\
31 \% \text { in non-EU markets and } 13 \% \text { in the } \\
\text { Lithuanian market. }\end{array}$ \\
\hline Potential of wind energy resources & Analysis of current situation & $\begin{array}{l}\text { In the Litgrid Network Development } \\
\text { Plan for 2020-2029 [28], it is foreseen that } \\
\text { total capacity of wind power plants will } \\
\text { increase to } 2.206 \mathrm{MW} \text { in } 2029 \text {, including } \\
700 \mathrm{MW} \text { off-shore wind farm. The } \\
\text { onshore wind capacity will increase by } \\
\text { approximately } 1.000 \mathrm{MW} \text {, i.e., from } \\
\text { current } 540 \mathrm{MW} \text { to } 1506 \mathrm{MW} \text {. }\end{array}$ \\
\hline Changes in energy structure & Statistical analysis & $\begin{array}{l}\text { Wind energy in electricity generation } \\
\text { from renewable energy sources } \\
\text { accounted for } 48 \% \text { in } 2015 \text { and } 61 \% \text { in } \\
2019 \text { in Lithuania [29]. }\end{array}$ \\
\hline
\end{tabular}

With reference to the information in Table 2, in a group of factor conditions, the lack of requested qualification staff is the most serious source of threat. Respondents noted that the business faces both: a shortage of skilled engineers and low-skilled staff. Other threats come from increasing cost of key production factors, including skilled labour, capital borrowing and energy. Most manufacturers of WEC procure raw materials on EU markets, but a third of them import raw materials from outside the EU and settle for raw materials using exchange rates other than EUR. Therefore, changes in exchange rates bring uncertainty. Respondents assessed the threat coming from the changes in exchange rate as low. Historically, the inflation rate was moderate in Lithuania (up to 10\% a year), and during some years, deflation was fixed (during 2014-2015, inflation was 0.1-0.3\% a year). Respondents assessed that threat (for example, reducing purchasing power of customers or orders of WEC) coming from increasing prices is low. The current status of production facilities assures the execution of orders. Manufacturers of WEC invest in update and development of production facilities. Since 2016, manufacturers of WEC have invested EUR 24.4 million a year when production volume has been EUR 250-300 million a year. Lithuania implements its Programme for Investment Promotion and Industry Development [30] by using EU Structural Funds and other resources which focus on 
linking industry and services to networks and industrial cooperation, increasing production of advanced technologies and using raw materials and energy efficiently. Respondents assessed that changes in investment environment are positive and promising. Moreover, within the Programme, the EU and national support measures are provided to address the aforementioned issues. Respondents assessed this as a medium to high opportunity. The market provides various financing sources to business. However, respondents assessed that the opportunities from this factor are medium, as the access conditions are strict. The share of wind energy in electricity production from renewable sources has been increasing in recent years in the country. The potential of wind energy resources and changes in the structure allow for the assumption that there are favourable conditions for the development of wind energy in Lithuania. The assessment of a group of condition factors and their tendencies show that these conditions are moderately favourable for manufacturers of WEC.

Two factors of the economic environment and two factors focusing on customers of WEC and the dynamics of sales of those components over the last five years included in the manufacturers of WEC survey are assigned to a group of demand conditions. The assessment of three factors described by statistical analysis is additionally added to a group of demand conditions (Table 3).

Table 3. Assessment of competitiveness factors: a group of demand conditions.

\begin{tabular}{|c|c|c|}
\hline Factors of Demand Conditions & Description & Assessment \\
\hline $\begin{array}{l}\text { Foreign market demand for "green" } \\
\text { products }\end{array}$ & Factor of economic environment & Opportunities 4.2 \\
\hline $\begin{array}{l}\text { Domestic market demand for "green" } \\
\text { products }\end{array}$ & Factor of economic environment & Opportunities 3.1 \\
\hline Energy demand & Statistical analysis & $\begin{array}{l}\text { The final electricity consumption } \\
\text { changed insignificantly in Lithuania } \\
\text { during 2016-2020. Consumption } \\
\text { increased by 6.2\% from 2016-2020 but } \\
\text { decreased by 2\% from 2019-2020. Since } \\
\text { 2018, electricity consumption has been } \\
\text { declining in industry and households, } \\
\text { but household consumption has } \\
\text { increased in } 2020 \text { [29]. }\end{array}$ \\
\hline Demand structure & $\begin{array}{l}\text { Question: Who are the customers of wind } \\
\text { energy components produced by the } \\
\text { company? }\end{array}$ & $\begin{array}{l}\text { Manufacturers of wind power plants and } \\
\text { their components ( } 58 \% \text { of respondents), } \\
\text { wind power plant construction } \\
\text { (installation) companies ( } 33 \% \text { ) and } \\
\text { companies for wind power plant } \\
\text { maintenance services }(8 \%) \text {. }\end{array}$ \\
\hline Demand dynamics & $\begin{array}{c}\text { Question: How have the sales volumes of } \\
\text { wind energy components produced in the } \\
\text { company changed during the last } 5 \\
\text { years? }\end{array}$ & $\begin{array}{c}\text { Decreased (40\% of Respondents), } \\
\text { increased }(30 \%) \text { and unchanged }(30 \%) \text {. }\end{array}$ \\
\hline Installed wind energy capacity & Statistical analysis & $\begin{array}{l}\text { The installed capacity of wind power } \\
\text { plants was } 0.5 \mathrm{GW} \text { in Lithuania in } 2019 \text {. } \\
\text { It increased by } 0.2 \mathrm{GW} \text { in } 5 \text { years. The } \\
\text { installed capacity of wind power plants } \\
\text { was } 167.1 \mathrm{GW} \text { in EU in } 2019 \text {. It increased } \\
\text { by } 51.5 \mathrm{GW} \text { in } 5 \text { years [31]. Wind power } \\
\text { installations have fallen by } 6 \% \text { to } 14.7 \\
\text { GW in } 2020 \text { in EU [32]. }\end{array}$ \\
\hline
\end{tabular}

The changing attitudes of consumers searching for sustainable, environment-friendly solutions increase the demand for "green" products. As it is seen from Table 3, due to expressed demand for "green" products, opportunities arise for the manufacturers of 
WEC. Subject to the fact that the Lithuanian market is small for conducting business, opportunities provided by foreign markets demand for "green" products were assessed higher than those provided by the domestic market. Demand structure is not homogeneous as it is formed by the manufacturers of wind power plants and their components, the companies constructing wind power plants and the companies providing maintenance services to wind power plants. The demand structure allows for the assumption that the WEC for wind power plants installed in Lithuania are applied in different stages of the production and maintenance of wind power plants and may have the potential to increase by expanding the construction of wind power plants. The dynamics of demand over the last 5 years show that WECs sales have changed slightly, as $40 \%$ of the respondents said that sales were declining, and 30\% said that they were increasing or did not change. The installed wind energy capacity has been growing in Lithuania since 2008 but has remained constant since $2016(0.5 \mathrm{GW})$. The installed wind power capacity in the EU market is constantly growing, only decreasing by $5.8 \%$ in 2020 due to the COVID-19 pandemic. The International Renewable Energy Agency (IRENA) predicts that wind energy will meet $35 \%$ of total energy demand by 2050 in order to meet the climate change targets of the Paris Agreement. In this way, the installed wind power capacity must triple by 2030 and increase nine times by 2050 compared to 2018. Asia (mainly China) will dominate in installed onshore wind power capacities (more than 50\% in 2050), while in Europe, 10\% will be installed. Accordingly, with $60 \%$ of installed capacity, Asia will be the leader in offshore wind power capacities, too; in Europe $22 \%$ of offshore wind power capacities will be installed [33]. In this way, the demand conditions to produce WEC show positive trends and can be welcomed.

Four factors are assigned to a group of factors of related and supporting industries. They are included in the survey to manufacturing companies and refer to the questions about the customers of WEC, the suppliers of raw materials and the sales intermediaries (Table 4).

Table 4. Assessment of factors of a group of related and supporting industries.

\begin{tabular}{|c|c|c|}
\hline $\begin{array}{l}\text { Factors of A Group } \\
\text { of Related and } \\
\text { Supporting } \\
\text { Industries }\end{array}$ & Description & Assessment \\
\hline $\begin{array}{l}\text { Wind turbine } \\
\text { manufacturers }\end{array}$ & \multirow{2}{*}{$\begin{array}{l}\text { Question: Who are the customers of } \\
\text { wind energy components produced } \\
\text { in the company? }\end{array}$} & \multirow{2}{*}{$\begin{array}{l}\text { Manufacturers of wind power plants and their components (58\% of respondents) } \\
\text { wind power plant construction (installation) companies ( } 33 \%) \text {, companies for } \\
\text { wind power plant maintenance services }(8 \%) \text { and other (to be identified) }(0 \%) \text {. }\end{array}$} \\
\hline Grid constructors & & \\
\hline $\begin{array}{l}\text { Raw material } \\
\text { suppliers }\end{array}$ & $\begin{array}{l}\text { Question: How many suppliers of } \\
\text { materials and raw materials does } \\
\text { the company have for the } \\
\text { production of wind energy } \\
\text { components? }\end{array}$ & $\begin{array}{l}\text { 3-10 raw material suppliers ( } 60 \% \text { of respondents), more than } 10(30 \%) \text { and a } \\
\text { single supplier }(10 \%) .\end{array}$ \\
\hline Sales intermediaries & $\begin{array}{l}\text { Question: How many sales } \\
\text { intermediaries are involved in the } \\
\text { distribution of wind energy } \\
\text { components produced by the } \\
\text { company? }\end{array}$ & $\begin{array}{l}\text { No sales intermediaries at all (55\% of respondents), one }(27 \%) \text {, and more than } 3 \\
(18 \%) .\end{array}$ \\
\hline
\end{tabular}

Assessing the factors of a group of related and supporting industries, it is found that the manufacturers of wind power plants and their components, the companies constructing wind power plants, and the companies providing wind power plant maintenance services are the key related and supporting industries. Grid constructors were not identified as related and supporting industries for Lithuanian manufacturers of WEC. The suppliers of raw materials are related and supporting industries uphold the competitiveness of manufacturers of WEC. It was found that the majority of manufacturers of WEC have 3-10 raw material suppliers; one-third of those companies demand raw materials from more than 10 suppliers, but up to $10 \%$ of manufacturers of WEC are dependent on a single supplier. The sales intermediaries are less important in this group of factors, as a significant proportion (55\%) of manufacturers of WEC answered that they do not have 
sales intermediaries. According to the results of the survey of manufacturers of WEC, it is seen that they usually communicate with their customers without intermediaries, have regular suppliers of raw materials; therefore, there is some synergy between related and supporting industries.

Three factors (Table 5) were prescribed to a group of firm strategy, structure and rivalry. Seeking to analyse them, six questions were formed in the questionnaire for the survey of manufacturers of WEC. The content of those questions referred to the groups of WEC that the manufacturers produce, the shares of WEC in the production structures, the shares of WEC exports, the export markets and the domestic and foreign competitors.

Table 5. Assessment of firm strategy, structures and rivalry.

\begin{tabular}{|c|c|c|}
\hline $\begin{array}{c}\text { Factors of Firm Strategy, } \\
\text { Structure and Rivalry }\end{array}$ & Description & Assessment \\
\hline Differentiation strategies & $\begin{array}{c}\text { Questions: 1. Which groups of WEC does } \\
\text { the company produce and / or could } \\
\text { produce in future? 2. What is the share of } \\
\text { WEC in the company's total production } \\
\text { volume? }\end{array}$ & $\begin{array}{c}\text { Mechanical, electrical, electronic, thermal, } \\
\text { composite and other components. } \\
\text { WEC make 15\% in the company's production } \\
\text { volume (in 70\% of surveyed WEC companies), } \\
70 \% \text { (in 10\% of surveyed WEC companies), } \\
95-100 \% \text { (in 20\% of surveyed WEC companies) }\end{array}$ \\
\hline Export & $\begin{array}{c}\text { Questions: 1. What is the share of WEC } \\
\text { in the total production volume that the } \\
\text { company exports? 2. To which countries } \\
\text { does the company export it's WEC? }\end{array}$ & $\begin{array}{c}\text { More than 50\% (70\% of surveyed WEC companies) } \\
\text { EU member states are key export markets (62\% of } \\
\text { surveyed WEC companies); 38\% of surveyed WEC } \\
\text { companies export to other countries than EU. }\end{array}$ \\
\hline Competitors & $\begin{array}{c}\text { Questions: 1. How many companies in } \\
\text { the Lithuanian market are the company's } \\
\text { competitors in the production of WEC? 2. } \\
\text { How many companies in foreign markets } \\
\text { are the company's competitors in the } \\
\text { production of WEC? }\end{array}$ & $\begin{array}{c}\text { competitors and 40\% of companies do not have } \\
\text { competitors at all in Lithuania. } \\
\text { WEC companies compete with more than 3 } \\
\text { competitors, except for 1 WEC company, which } \\
\text { has up to 3 competitors in foreign markets. }\end{array}$ \\
\hline
\end{tabular}

According to the factor of differentiation strategy, it was found that the manufacturers of WEC produce various components, but usually they are not the only products they manufacture. Several companies specialize in WEC production; therefore, WEC make up to $95-100 \%$ of the production structure. Exports of WEC are quite widely developed among the surveyed manufacturers. They mainly export to EU countries, but $38 \%$ of the surveyed manufacturers of WEC export their products to other countries of the world, too. Lithuanian companies are too small to attract the largest wind power manufacturers. Competition in the Lithuanian market is not high, and some manufacturers of WEC have no competitors at all $(40 \%)$. Competition in the foreign markets is high, but due to the specifics of the products, it is not very intense. In any case, international competition is not beneficial for Lithuanian producers due to the low costs of producers from other countries. Most of the surveyed companies indicated that they are subdivisions of global enterprise groups. Therefore, they face the following difficulties:

- they cannot apply for Lithuanian and EU financial support;

- it is difficult to become a direct supplier due to the complex organization with the customer;

- by managing risks, customers regulate all processes at their direct suppliers;

- unattractive obligations when working with large groups-binding warranty conditions for products, strict requirements for quality and supply indicators.

- high penalties are provided for delays or non-compliance with other obligations.

As opportunities to address issues related to firm strategy, structure and rivalry factors, companies see opportunities to look for partners who are already working with power plant manufacturers and aspire to be second or third in the supply chain. 
Six factors of political environment and one factor of the economic environment were prescribed to a group of governmental factors. They were assessed as an average of results from the survey of manufacturers of WEC and expert assessment (Table 6).

Table 6. Assessment of governmental factors.

\begin{tabular}{|c|c|c|}
\hline Governmental Factors & Description & Assessment \\
\hline EU and Lithuanian emissions' reduction targets & Factor of political environment & Opportunities 3.7 \\
\hline $\begin{array}{c}\text { Targets and support measures for increasing the } \\
\text { production and consumption of energy from } \\
\text { renewable sources in Lithuania }\end{array}$ & Factor of political environment & Opportunities 3.3 \\
\hline $\begin{array}{c}\text { Regional development policy, its objectives and } \\
\text { support measures }\end{array}$ & Factor of political environment & Opportunities 3.0 \\
\hline Phase out of subsidies for fossil fuels & Factor of political environment & Opportunities 2.9 \\
\hline Energy efficiency targets and support measures & Factor of political environment & Opportunities 2.3 \\
\hline Taxes & Factor of economic environment & Threats 3.1 \\
\hline $\begin{array}{c}\text { Requirements for the management and utilization of } \\
\text { waste generated in the production process }\end{array}$ & Factor of political environment & Threats 2.4 \\
\hline
\end{tabular}

The group of governmental factors is dominated by the factors of political environment. One factor of the economic environment was included. According to the Respondents, governmental decisions provide companies with more opportunities than threats. The most immense opportunities can be provided by the EU and Lithuanian emissions' reduction targets, followed by targets and support measures for increasing the production and consumption of energy from renewable sources in Lithuania, as well as regional development policy, its objectives and support measures as the factors create demand for WEC, facilitate business doing in places favourable to development of wind energy or to relevant infrastructure (for example, seaports).

Companies, naming opportunities for the development of their activities, indicate that the governmental decisions could stimulate it:

- taxation of profits only by withdrawing funds from the company would encourage shareholders to invest more in Lithuania by increasing the value of the company;

- the form of business promotion and taxation used in free economic zones' territories would be adapted for entire regions;

- providing equal opportunities to foreign and Lithuanian capital companies; promotion of Lithuanian capital investments in manufacturing companies;

- promotion of the establishment of joint Lithuanian and foreign capital companies with know-how experience.

Three factors of technological environment were prescribed to a group of technological factors (Table 7).

Table 7. Assessment of technological factors.

\begin{tabular}{|c|c|c|}
\hline Technological Factors & Description & Assessment \\
\hline Implementation of the latest technologies & Factor of technological environment & Opportunities 3.8 \\
\hline $\begin{array}{c}\text { Dynamics of technological change and } \\
\text { innovation implementation }\end{array}$ & Factor of technological environment & Opportunities 3.3 \\
\hline Expenditure on R \& D & Factor of technological environment & Opporties 2.5 \\
\hline
\end{tabular}

As it is seen from Table 7, the introduction of the latest technologies, dynamics of technological changes and innovations and $\mathrm{R} \& \mathrm{D}$ expenditures may provide medium to high opportunities to manufacturers of WEC. 
The impact of a chance on the competitiveness of the manufacturers of WEC is assessed only based on the results of an experts' survey. Its importance is scored as 3.25 on a 5-point rating scale.

\subsection{Assessment of the Importance of Groups of Competitiveness Factors and the Competitiveness of WEC Companies}

Assessment of the competitiveness factors of manufacturers of WEC was performed in three stages. The first stage examined the factors of business environment (analysis of responses of surveyed manufacturers of WEC and experts). In the second stage, the factors of business environment were summarized and supplemented by the factors of statistical and current situation analysis. In the third stage, the assessment results of the importance of the groups of competitiveness factors were summarized according to the results of the surveyed experts (Table 8).

Table 8. Assessment of the importance of the factors determining the competitiveness of manufacturers of WEC.

\begin{tabular}{|c|c|c|c|}
\hline Groups of Factors & Average of Assessment Score & Minimum Assessment Score & Maximum Assessment Score \\
\hline Factor conditions & 5 & 5 & 5 \\
\hline Demand conditions & 3.3 & 1 & 5 \\
\hline $\begin{array}{c}\text { Related and supported } \\
\text { industries }\end{array}$ & 3.5 & 2 & 5 \\
\hline $\begin{array}{c}\text { Firm strategy, structure and } \\
\text { rivalry }\end{array}$ & 4 & 3 & 5 \\
\hline $\begin{array}{c}\text { Government } \\
\text { Chance }\end{array}$ & 4 & 2 & 5 \\
\hline
\end{tabular}

Assessing the importance of the factors determining the competitiveness of manufacturers of WEC, experts unanimously agree that the factor conditions are the most important. However, the other factors mentioned were also considered to be quite important.

The firm strategy, structure and rivalry and the government were assessed as very important by experts too (the average score is 4.0). The analysis of individual factors of these groups revealed that Lithuanian manufacturers of WEC are characterized by their activity differentiation, the development of their exports to the EU and other countries and that they do not face the intense competition.

The importance of related and supporting industries for the competitiveness of manufacturers of WEC was assessed by experts at the average score of 3.5. The analysis of individual factors showed that companies engaged in these activities sell their products without the intermediaries, have regular suppliers of raw materials and a list of different customers, including manufacturers of wind turbines and their components, companies constructing and installing wind power plants and companies providing maintenance services to wind power plants.

The demand conditions and the impact of the chance were assessed as the least important in comparison to other discussed factors. Their average score is 3.3. Nevertheless, the analysis of demand factors has revealed that they are favourable and positively affect the competitiveness of WEC companies.

The methodology developed and applied for the research of the competitiveness of the industrial companies forming the VCWEC in Lithuanian is universal and may be applied to other research in other countries'. The manufacturer surveys and expert assessments may reveal completely different results in larger countries with more developed industries. It would be useful to carry out such a study in the context of EU countries. In this case, it might be challenging to assess government factors as they can vary significantly from one EU country to another. This may be a further area of research.

Competitiveness assessment studies often face difficulties in conducting quantitative assessments, as competitiveness models cover a wide range of factors, but most of them cannot be quantified, so qualitative assessment methods have to be applied. 
A short (half a year) project implementation deadline and the quarantine made data collection more complex. With more time for companies to be interviewed and opportunities to meet, the study results might reveal slightly different results.

\section{Conclusions}

The research was conducted applying methods such as a survey of manufacturers of WEC, expert assessment and descriptive analysis

Summarizing the factors assigned to the groups of factors assessing the competitiveness of Lithuanian industrial companies forming VCWEC assessed according to the results of companies' survey and experts' assessment, it is seen that the greatest opportunities are provided by demand conditions (3.6), followed by factor conditions (3.4), government (3.3) and technology (3.3). The threats are posed by factor conditions (3.7) and government (2.8). The analysis disclosed that the existing conditions are sufficiently favourable for the competitiveness of Lithuanian industrial companies forming the VCWEC.

According to experts, financial reasons and insufficient state legal regulation are the main obstacles that make it difficult for companies to join and/or operate in the VCWEC in Lithuania.

The interviewed Lithuanian industrial companies forming the VCWEC identified the following difficulties for their performance:

- The size of Lithuania and its industry is too small to attract large wind power manufacturers;

- Competition with producers and service providers in low-cost countries is high;

- There is a lack of both low-skilled and skilled workers with engineering education.

The survey of manufacturers revealed that most of them are entities of global enterprise groups. For this reason, they face the following difficulties:

- They are not eligible for Lithuanian and EU financial support;

- It is difficult to become a direct supplier;

- Complex qualification process: managing risks customer companies regulate all processes at their direct suppliers;

- Unattractive obligations when working with large corporations: binding warranty conditions for products, strict requirements for quality and supply indicators. High fines for delays or non-compliance with other obligations.

The interviewed manufacturers see the following opportunities for improvement or development of their performance and the measures that would help to implement them:

- Finding partners who are already working with the power plant manufacturers, be second or third in the supply chain and thus avoid much of bureaucracy working directly;

- Applying corporate income tax only by withdrawing funds from the company would encourage shareholders to invest more in Lithuania by increasing the company's value;

- Applying enterprise promotion and taxation that are used in free economic zones territories for entire regions;

- Ensuring the education of more engineering professionals and creating better conditions for the employment of missing professionals from third countries;

- Promoting Lithuanian capital investments in manufacturing companies;

- Encouraging the establishment of joint Lithuanian and foreign capital companies with know-how.

The research results reveal that government solutions to promote industry could facilitate the activities of Lithuanian industrial companies forming VCWEC and encourage new companies to join it. This could encourage the Lithuanian industry to participate in the value chain of the EU's renewable energy industry, create more jobs and increase the value-added created.

Author Contributions: Conceptualization: D.D. and A.C.; methodology: D.D., A.C. and V.B.; software: A.C.; validation: A.C. and V.B.; investigation: D.D., A.C. and V.B.; supervision: E.D.; writing 
and review: D.D., A.C. and V.B. All authors have read and agreed to the published version of the manuscript.

Funding: This research "Feasibility study of Lithuanian industry participation in the value chain of wind energy components. (VEGRAND)" is funded by the Research Council of Lithuania under Grant No. S-REP-21-5.

Institutional Review Board Statement: Not applicable.

Informed Consent Statement: Not applicable.

Conflicts of Interest: The authors declare no conflict of interest. The funders had no role in the design of the study; in the collection, analyses, or interpretation of data; in the writing of the manuscript; or in the decision to publish the results.

\section{References}

1. Wind Europe. Wind Energy and Economic Recovery in Europe. How Wind Energy Will Put Communities at the Heart of the Green Recovery. Available online: https://windeurope.org/intelligence-platform/product/wind-energy-and-economicrecovery-in-europe/ (accessed on 4 August 2021).

2. U.S. Department of Energy: Energy Efficiency \& Renewable Energy. PowerPoint Version of the Wind Energy Integration Slideshow. Available online: https://windexchange.energy.gov/slideshows (accessed on 4 August 2021).

3. European Commission. Quarterly Report on European Electricity Markets with Focus on the Developments in Annual Wholesale Prices. Available online: https://ec.europa.eu/energy/sites/default/files/quarterly_report_on_european_electricity_markets_ q4_2020.pdf (accessed on 4 August 2021).

4. Bobinaite, V.; Priedite, I. RES-E support policies in the Baltic States: Price aspect (Part 2). Latv. J. Phys. Tech. Sci. $2015,52,13-25$.

5. Ju, X.; Liu, F. Wind farm layout optimization using self-informed genetic algorithm with information guided exploitation. Appl. Energy 2019, 248, 429-445. [CrossRef]

6. Bobinaite, V.; Priedite, I. Assessment of impacts of wind electricity generation sector development: Latvian case. Procedia Soc. Behav. Sci. 2015, 213, 18-24. [CrossRef]

7. Li, J.; Li, S.; Wu, F. Research on carbon emission reduction benefit of wind power project based on life cycle assessment theory. Renew. Energy 2020, 155, 456-468. [CrossRef]

8. Ju, X.; Liu, F.; Wang, L.; Lee, W.-J. Wind farm layout optimization based on support vector regression guided genetic algorithm with consideration of participation among landowners. Energy Convers. Manag. 2019, 196, 1267-1281. [CrossRef]

9. World Economic Forum (WEF). Global Competitiveness Report 2014-2015. Geneva. Available online: http:/ / reports.weforum. org/global-competitiveness-report-2014-2015/ (accessed on 18 May 2021).

10. Vivien, W. Technology and the economy-The key relationships: (Organisation for economic co-operation and development, Paris, 1992) pp. 328, 260 FF. Res. Policy 1994, 23, 473-475.

11. International Institute for Management Development (IMD). World Competitiveness Yearbook 2014. Available online: https: / / www.imd.org/research-knowledge/articles/com-may-2014/ (accessed on 15 May 2021).

12. Smith, A. The Wealth of Nations: An Inquiry into the Nature and Causes of the Wealth of Nations. Harriman House Limited. 2007. Available online: https://www.ibiblio.org/ml/libri/s/SmithA_WealthNations_p.pdf (accessed on 20 May 2021).

13. Ricardo, D. On the Principles of Political Economy and Taxation. (Original Work Published 1817, Third Edition 1821). London: Dent 2001. Available online: https:/ / socialsciences.mcmaster.ca (accessed on 20 May 2021).

14. Krugman, P.R. Making sense of the competitiveness debate. Oxf. Rev. Econ. Policy 1996, 12, 17-25. [CrossRef]

15. Siudek, T.; Zawojska, A. Competitiveness in the economic concepts, theories and empirical research. Acta Sci. Pol. Oeconomia 2014, 13, 91-108.

16. Beniušienè, I.; Svirskienè, G. Konkurencingumas: Teorinis aspektas. Ekon. Vadyb. Aktual. Perspekt. 2008, 4, 32-40.

17. Porter, M.E. The competitive advantage of nations. Compet. Intell. Mag. 1990, 1, 14.

18. Fang, K.; Zhou, Y.; Wang, S.; Ye, R.; Guo, S. Assessing national renewable energy competitiveness of the G20: A revised Porter's Diamond Model. Renew. Sustain. Energy Rev. 2018, 93, 719-731. [CrossRef]

19. Travkina, I.; Tvaronavičienè, M. An Investigation into Relative Competitiveness of International Trade: The Case of Lithuania. Available online: http:/ / dspace.vgtu.lt/bitstream/1/597/1/504-510_Travkina_Tvaronaviciene.pdf (accessed on 18 May 2021).

20. Lietuvos Pramonès Eksporto Konkurencingumo Vertinimas. Available online: https://www.vdu.lt/cris/bitstream/20.500.12259 /1221/1/ISSN1822-7996_2012_T_6_N_2.PG_49_72.pdf (accessed on 18 May 2021).

21. Key Issues in Defining and Analysing the Competitiveness of a Country. Available online: https://papers.ssrn.com/sol3/papers. cfm?abstract_id=418540 (accessed on 18 May 2021).

22. Balkytè, A.; Tvaronavičienè, M. Perception of competitiveness in the context of sustainable development: Facets of "sustainable competitiveness". J. Bus. Econ. Manag. 2010, 11, 341-365. [CrossRef]

23. Zhao, Z.Y.; Hu, J.; Zuo, J. Performance of wind power industry development in China: A DiamondModel study. Renew. Energ. 2009, 34, 2883-2891. [CrossRef] 
24. Liu, J.; Wei, Q.; Dai, Q.; Liang, C. Overview of wind power industry value chain using diamond model: A case study from China. Appl. Sci. 2018, 8, 1900. [CrossRef]

25. Irfan, M.; Zhao, Z.Y.; Ahmad, M.; Mukeshimana, M.C. Critical factors influencing wind power industry: A diamond model based study of India. Energy Rep. 2019, 5, 1222-1235. [CrossRef]

26. Zhang, S. International competitiveness of China's wind turbine manufacturing industry and implications for future development. Renew. Sust. Energ. Rev. 2012, 16, 3903-3909. [CrossRef]

27. Legendre, P. Coefficient of concordance. Encycl. Res. Des. 2010, 1, 164-169.

28. Litgrid. Lietuvos Elektros Energetikos Sistemos 400-100 kv Tinklu Plètros Planas 2020-2029 m. Vilnius 2020. Available online: https:/ / www.vert.lt/SiteAssets/posedziai/2021-02-19/litgrid_planas_priedas_1.pdf (accessed on 12 June 2021).

29. Lietuvos Statistika. Rodikliu Domenu Bazè-Oficialiosios Statistikos Portalas. Available online: https://osp.stat.gov.lt/statistiniurodikliu-analize\#/ (accessed on 13 July 2021).

30. Programme for Investment Promotion and Development of Industry during 2014-2020. Available online: https: / e-seimas.lrs.lt/ portal/legalAct/lt/TAD/731c6e80457911e4ba35bf67d0e3215e (accessed on 11 August 2021).

31. Eurostat. 2021. Available online: https:/ / ec.europa.eu/ eurostat/data/database (accessed on 6 June 2021).

32. Wind Europe. Wind Energy in Europe 2020 Statistics and the Outlook for 2021-2025. Available online: https: / / windeurope.org/ intelligence-platform/product/wind-energy-in-europe-in-2020-trends-and-statistics/ (accessed on 14 July 2021).

33. IRENA. Future of Wind: Deployment, Investment, Technology, Grid Integration and Socio-Economic Aspects. A Global Energy Transformation Paper. International Renewable Energy Agency 2019, Abu Dhabi. Available online: https:/ / www.irena.org/- / media/files/irena/agency/publication/2019/oct/irena_future_of_wind_2019.pdf (accessed on 14 July 2021). 